\title{
The Multimodal Construction of Brexit in the Economist (2017 - 2021)
}

Kalina Ishpekova-Bratanova, PhD'

Received: 09.08.2021

Available online: 20.12.2021

\begin{abstract}
This paper aims to show how and why the Economist constructs the post-Brexit European Union's (EU) image in a string of commentaries published in the Charlemagne section in the 2017-2021 period. The theoretical concepts that provide the interdisciplinary methodological framework within which the research topic - the exposure of the discursive and cognitive mechanisms whereby the global media of British origin constructs the EU's image and frames the debate about the EU - is explored encompass social semiotics and critical discourse analysis. The findings suggest that through its interplay of headline and subheading, together with the cartoon and textual body, the Economist holds the assumption that Brexit threatens the cohesion of the EU and prompts the drawing of a new balance of interests.
\end{abstract}

Keywords: Brexit, Britishness, multimodal metaphor, critical discourse analysis

JEL: Z18

\section{Introduction}

This paper makes an attempt to expose how and why the Economist constructs the post-Brexit European Union's (EU) image in a string of commentaries published in the Charlemagne section in the period 2017-2021. The chosen period is immediately before and after the United Kingdom left the club. There are a number of reasons that conditioned the choice of this specific research object. Given its long-standing history of editorial and political independence, the Economist is a media outlet of global impact - an undisputed leader in shaping public opinion worldwide, while Charlemagne section specifically addresses EU-related issues. The newspaper's materials are based on checked facts and statistics to present commentaries offering a multitude of opinions and viewpoints on

1 Senior lecturer in English language, Department of Foreign Languages and Applied Linguistics, UNWE; e-mail: kalina.bratanova@unwe.bg 
the examined topical issues of the international arena (for a more detailed analysis of the Economist's business model and target readership, editorial policy and thematic range expansion since its creation in 1843 see Ishpekova-Bratanova, 2020: 79-90). The research topic is to expose the discursive and cognitive mechanisms (multimodal metaphors, metaphorical scenarios and mini-narratives, together with symbols, intertextuality, and figures of speech) whereby the global media of British origin constructs the EU's image and frames the debate about the EU.

After all, the Economist boasts an idiosyncratic language and style, which is characterized by genre-specific elements of formal and recurrent linguistic structures in terms of semantics, pragmatics, and stylistics.

The assumption is held that, considering its British origin and identity, the Economist frames the debate, implicitly suggesting its Eurosceptic attitude to the EU-related events and issues that are addressed in the commentaries (for a detailed opinion, see IshpekovaBratanova, 2021). The emphasis in the selected empirical material is put on the far-reaching implications for the EU's future amid rising populism and nationalism, the latter admittedly being attributable to the growing discontent with globalization and universalist values.

\section{Brexit and Britishness}

In purely political terms, Brexit can be regarded as the cross-section between Euroscepticism and Britishness. Brexit as a process is rooted in a broader historical context suggesting that the factor of British identity and values played a central role in this complex and unprecedented event with serious repercussions worldwide. It is a foundation on which rests the UK's complicated existence with and within the EU. This problematic past started way back in 1963 when Charles De Gaulle twice vetoed British membership in the Common Market. Ever since the UK has been seen as an island, taking the position of EU's awkward partner, of the odd man out within the European community (see the special report in the Economist, 2015). It is no coincidence that British experts and researchers have regarded the union as vague, given the ongoing tensions between breadth versus depth of integration, between national sovereignty and supranational powers. The proEuropean stance taken by Edward Heath's government in the 1970s, later on followed by Margaret Thatcher was prompted mainly by economic motives such as the access to the European markets, the increase of the UK industry's competitiveness. The political motives pertained to the possible restoration of the country's position as a global power lost after World War II, particularly after the Suez crisis of 1956. The first problems with Europe stemmed from the financing and spending of the common European budget, a problem resolved during the European Council summit in 1984 in Fontainebleau.

Great Britain has always taken a firm stand against the political aspects of European integration and the establishment of an efficient political union, which was regarded as a threat to Britain's sovereignty in decision making. Thatcher supported free initiative and 
trade, and opposed the deeper political integration conditioned by the Single European Act and the creation of the EU.

The UK has always been reluctant to give up part of its identity and independence on the international arena. Among the factors that shaped the English (and British) identity are the country's geographical location, the specific domestic and foreign policy, identified by the British historian Tombs (see Tombs, 2015).

\section{Theoretical and methodological framework of analysis}

The major theoretical concepts that presumably provide the interdisciplinary methodological framework within which the research topic can possibly be explored encompass social semiotics, news framing and Critical Metaphor Analysis (CMA), the latter being the cross-section of Critical Discourse Analysis (CDA) and Conceptual Metaphor Theory (CMT). As a form of satirical journalism and a type of visual opinion news discourse (Greenberg, 2002), political cartoons belong to the editorial pages of the traditional newspaper. They occupy little space, and convey extremely complex information condensed into a single image, helping the reader understand politics by presenting an imaginary scenario of the real-life events (El Refaie, 2009) and thus performing a commenting, a clarifying or an evaluative function (Ibid). A generic convention of cartooning is that the goal is to expose "something bad or shameful rather than to highlight the positive" (El Rafaie, 2009: 176). As part of the media construction of social reality, political cartoons are a legitimate object of CDA, considering that they "continue to reflect cultural attitudes and values, and record and perpetuate many commonly held beliefs", communicating shrewd, complex multi-layered narratives about people that are difficult to express in words (Mazid 2008: 434-437).

The multimodal analysis of the verbal-visual combinations in the commentaries poses the highly relevant question of the relation between the image and the text in terms of how the cartoon adds to the commentary's overall coherence and cohesion or whether tension is created instead. According to social semiotics (Halliday and Hasan, 1985), language is conceptualized as culturally shaped interrelated sign systems, performing three intrinsic functions: the ideational meaning, whereby happenings and state-of-affairs are represented as well as their logical relations; the interpersonal meaning, whereby a stance is taken towards the represented world; and the textual meaning, whereby different elements are organized into a coherent message. These metafunctions and meanings are realized through different lexico-grammatical choices. Based on the assumption that nonverbal modes are also meaning-making resources (Halliday and Hasan 1985), Kress and van Leeuwen (2006) adapt the grammatical model of language to analyze visual design. Hence a sentence and its meaning can be conveyed with an image through the visual Transitivity configuration of an action process (Kress and van Leeuwen 2006, 63-66). Linguistic and visual transitivity share similar functional elements, namely participants, processes, and circumstances, though they have different semiotic forms of representation. Participants and 
processes in language usually take the grammatical forms of nouns and verbs respectively, while visual participants and processes are often depicted as shapes and vectors (lines of movement). Lexicogrammatical systems like Transitivity are primarily concerned with the structure in a sentence, while the system of cohesion includes non-structural resources to explore meaning relations between sentences in English including references, ellipsis and substitution, conjunction and lexical cohesion (Halliday and Hasan, 1976).

\section{Empirical analysis}

All actors and stakeholders involved in Brexit are presumably aware of the broader picture - that the future of Europe is linked to the outcome and the success of Brexit. As a non-state global actor in international relations, admittedly of British origin and identity, the Economist is no exception in this respect.

As multimodality is a focus in this piece of research, special attention will be paid to the political cartoons accompanying the text of the newspaper articles. All cartoons in the selected corpus of commentaries from the Charlemagne section of the Economist have been drawn by the award-winning artist Peter Schrank, who spent twenty years as a freelance cartoonist and illustrator in London and worked for the Economist, the Independent, the Business Post (Ireland) and the Times and Sunday Times (London)2.

In the studied period (2017-2020), the 17 articles were found (see table in notes).

This paper makes no claim to a comprehensive examination of all 17 articles. Hence the focus of investigation will be only some of these. For instance two articles - E9 and E12 - set out to explain why stereotypes rule in Brussels and why Britain and its neighbors tend to misunderstand each other. As a cosmopolitan place, Brussels should presumably be a place where "national stereotypes wither, as familiarity breeds content". Yet Eurocrats, and diplomats "revel in stereotyping that would make a 1970s sitcom writer blush", as entire regions are "condemned". It is a place where the essential differences between Catholic and Protestant Europe are highlighted, and where the EU southern states are "debt-addicted wasters", whereas the northern ones are "moralistic misers". Furthermore, "newer member-states and their objections are disregarded as adolescent moaning, whereas the good ideas put forward by the original six members are dismissed as Euro-aristocrats lording it over newer arrivals."

Stereotypes are described as a "coping mechanism for complexity" that can be used as a tool or a weapon in career development in Brussels, where "a stereotype is a mark of privilege as much as prejudice". The final conclusion is that the stereotype "can shape reality" and largely reflects voters' view of the different countries.

2 Available at: https://www.schrankartoons.com/ 


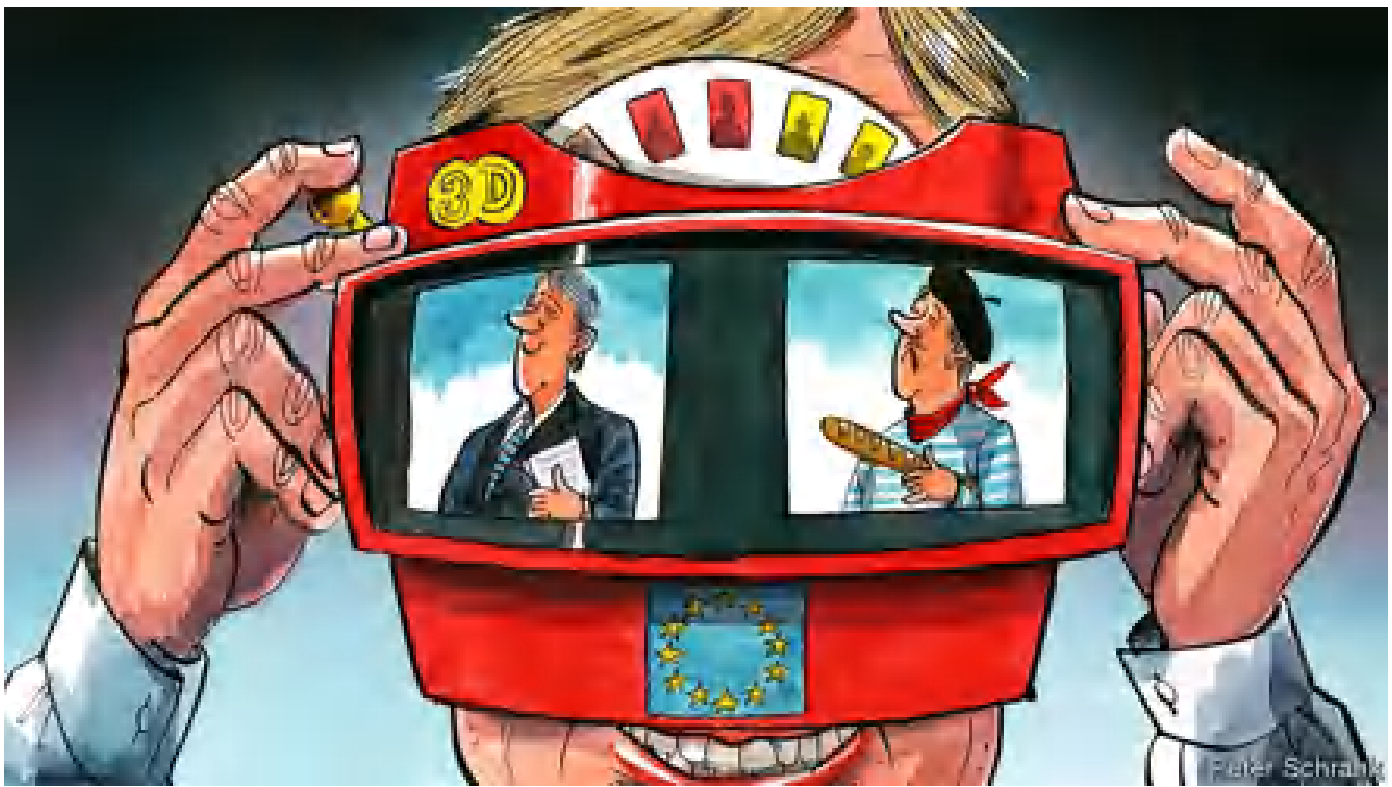

Source: The Economist (2020). "Why stereotypes rule in Brussels,

The EU's de facto capital has a dirty secret", 11 January 2020

The political cartoon represents the pictorial context within which these verbal assumptions are made and which largely frames the debate about national differences and stereotypes. The stereoscope, a tool devised back in the 1950s, takes center stage. As a device it is used to render 3D pictures. Hence stereotypes and 3D photos (or slides) are almost synonymous terms, given their principle of operation: there is a separate shot for each of the viewer's eye to create the illusion of a three-dimensional space. Each pair of photos is placed on a rotating disc, along which the member states are presumably placed. The major personage foregrounded is obviously the same person, given his physiognomy, so the shots should admittedly have minimal differences. The man on the left is wearing an official suit and stands for the French Eurocrat, who is holding tight a document of some kind and is smiling in a complacent manner. The man on the right is a typical French peasant wearing a sailor's T-shirt of the blue-and-white Breton stripe, holding a baguette with no smiling eyes or mouth.

E12 holds the view that the UK and the EU misunderstand each other. Glimpsed through continental eyes, Britain is an "exotically distinct place": in terms of architecture, culture, and institutions. Furthermore, the country is "strikingly mixed and multi-ethnic". The Brexit process illustrates how the two sides misunderstand each other. Britons tend to see the EU only at its extremes, in its most pragmatic and most idealistic forms: half trade accelerator and half highfalutin peace project. Likewise, Westminster parliamentarianism and Britain's common-law legal system run on common-sense specificity and abstract principle, not the codified layers between the two that define the mainland. Britons, who tend not to speak 
other languages, understand other Europeans more poorly than the other way around. What is more, continentals have long overlooked the adversarial nature of Britain's politics and assumed that its leaders "can fudge their way" to a compromise on Brexit. Calling on the two sides to take heed of their differences, the Economist ends on a pessimistic note: Brexit is a disaster that should be reversed; yet if it is, that will not settle Britain's relationship with its continent for one second.

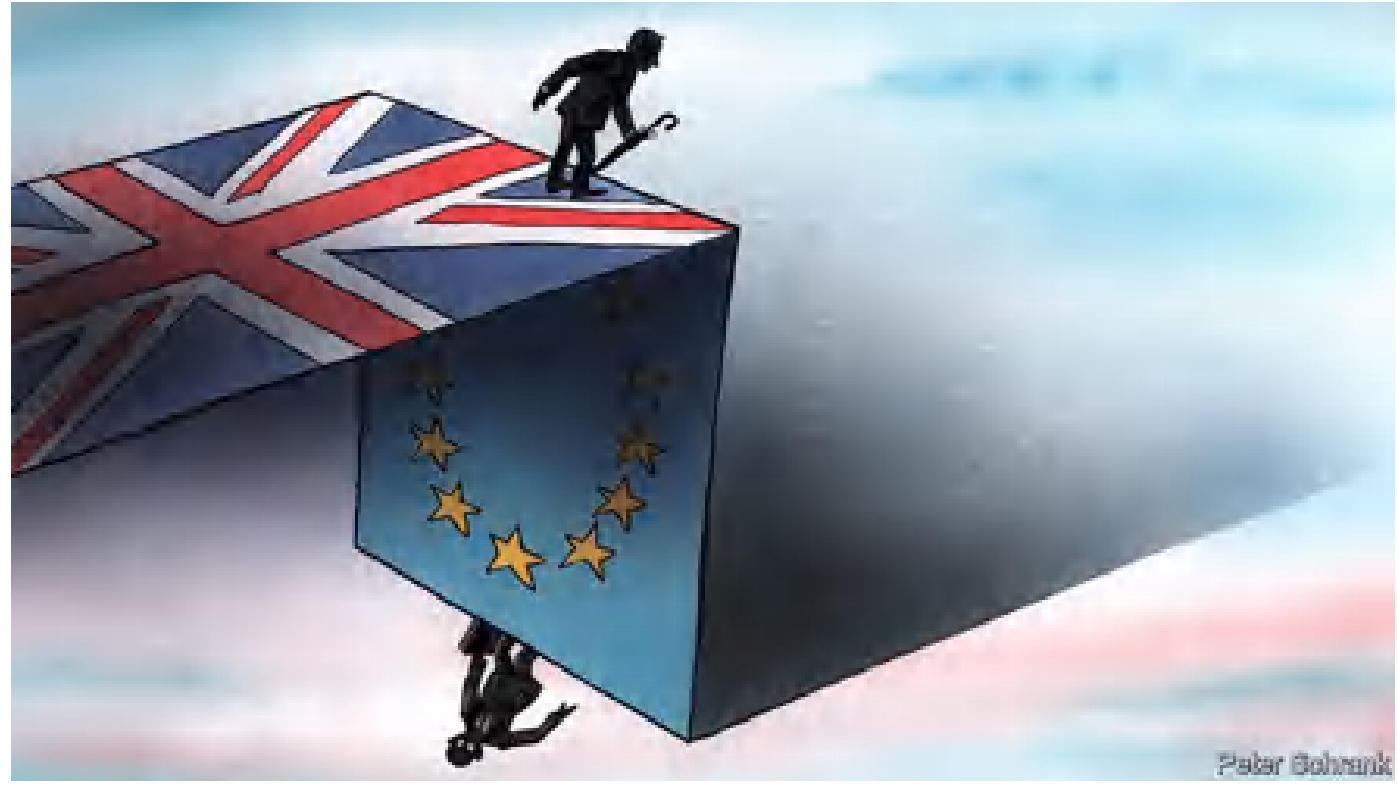

Source: The Economist (2019). "How Britain and its neighbours misunderstand each other, Both need to learn fast", 26 January 2019

The picture is based on the two dimensional illusion of a three-dimensional form. If the picture is turned at 180 degrees, a totally different situation looms up. The suggested normal sight of the picture features an individual who has walked his path all the way. He is presumably of British origin, which is suggested through certain details: as the Union Jack is along the path and the umbrella he is holding. He is full of hesitation about what comes beyond the edge - a chasm and a hazy horizon.

If the illustration is turned at 180 degrees, the other individual, of an unknown nationality (admittedly European because of the flag and the suit and suitcase), has also reached the edge of the road and is also unresolved and surprised by the obstacle ahead. He is uncertain whether he will cross the point of no return. He is supposedly to land on the opposite side of the Union Jack, while his gleaming eyes expose his supra-natural powers, something of a Spiderman. The posture of the British man, however, reveals his ease at walk and wary sight of the impending chasm.

E11 uses the metaphor of the British plug to comment on the EU's strange regulatory power, as the union prides itself on "the toughest regulations on everything from privacy to 
the environment", admittedly based on its big market and exacting rules and regulations. Hence the plug stands for a blend that the EU "has learned to master": good design combined with regulatory clout and market power. In other words, the British government is cherishing divergence at a time when convergence with the EU's rules is the order of the day at a time when globalisation increasingly resembles Europeanisation. However, the final warning suggests that heavy regulation may possibly be an obstacle to technological advancement.

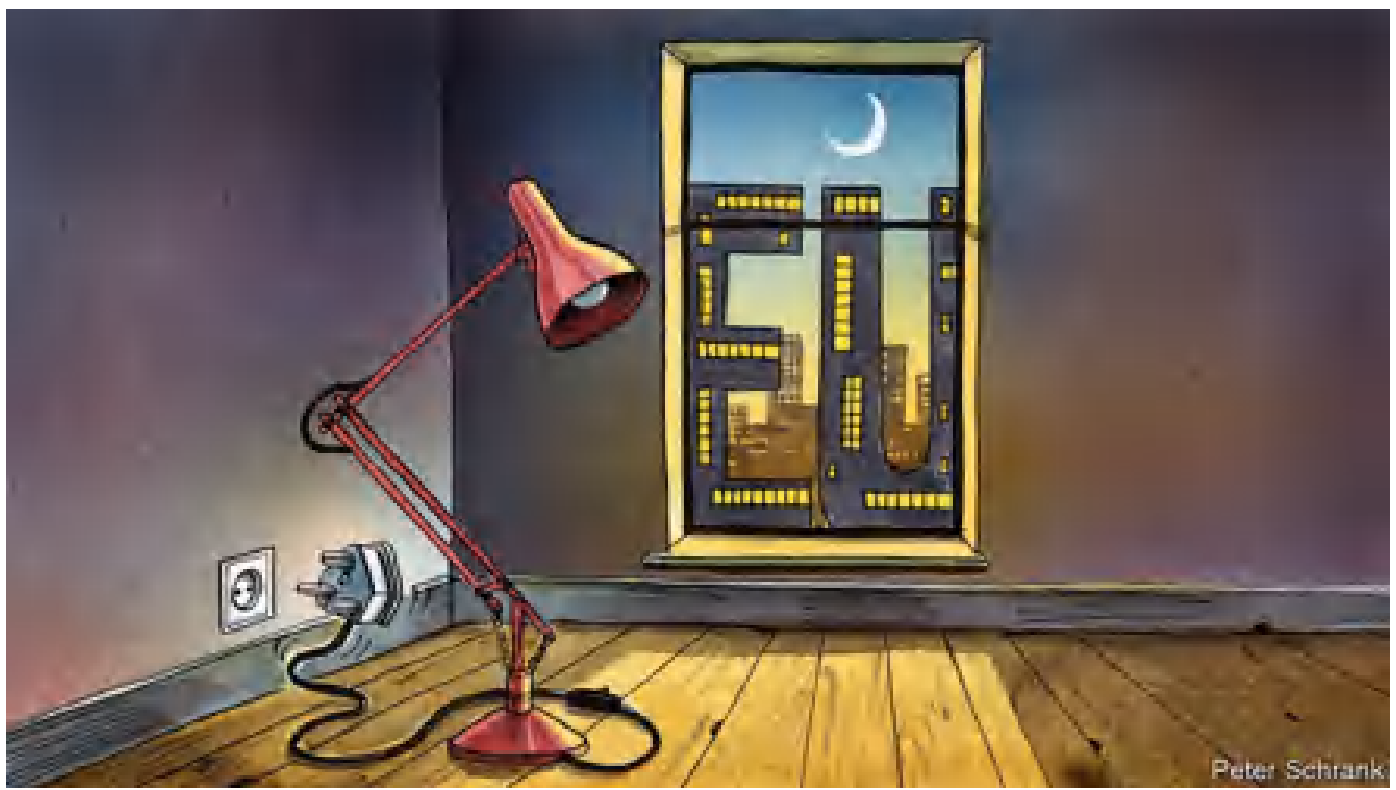

Source: The Economist (2020). "The parable of the plug, How plugs explain the potential and limits of the EU's strange superpower", 8 February 2020

The picture shows an empty and dark room in which the only source of light is the one coming from the window. The silhouettes of the metropolitan area are clearly seen, against the backdrop of the shining moon and the skyscrapers in the form of the EU. Streaming through the window, the light is cast upon the lamp that is the only piece of furniture in the empty room. Even though the lamp itself is a flexible device that could throw light on various surfaces and is obviously willing to do so, which is suggested through the plug rising like a cobra, this seems impossible. After all, the socket is a European standard, whereas the plug is British standard - the lamp plug is a bulky three-pronged one. What comes to mind is that as soon as night sets in and the EU puts out its lights, darkness will settle in and the lamp with the British plug will be useless.

There is an interesting interpretation of relations between member states as the Brexit process was drawing close to an end. E8 headlined Europe's gaseous political alliances sets out to explain why "the old Franco-German pact has given way to shifting coalitions", as the subheading suggests. The picture reveals interesting symbols and personages. The 
symbols are Austria's double-headed eagle of the Habsburg monarchy, as well as the crown as the symbol of the monarchy, whether that of Spain or the Netherlands. French President Macron and German Chancellor Merkel are depicted as sorcerers bent over the typical cauldron out of which vapors are emanating that take the form of the EU, which is dynamically changing its shape. It is under their incantations that the two symbols have emerged, and so has the EU depicted as a constantly changing gaseous substance.

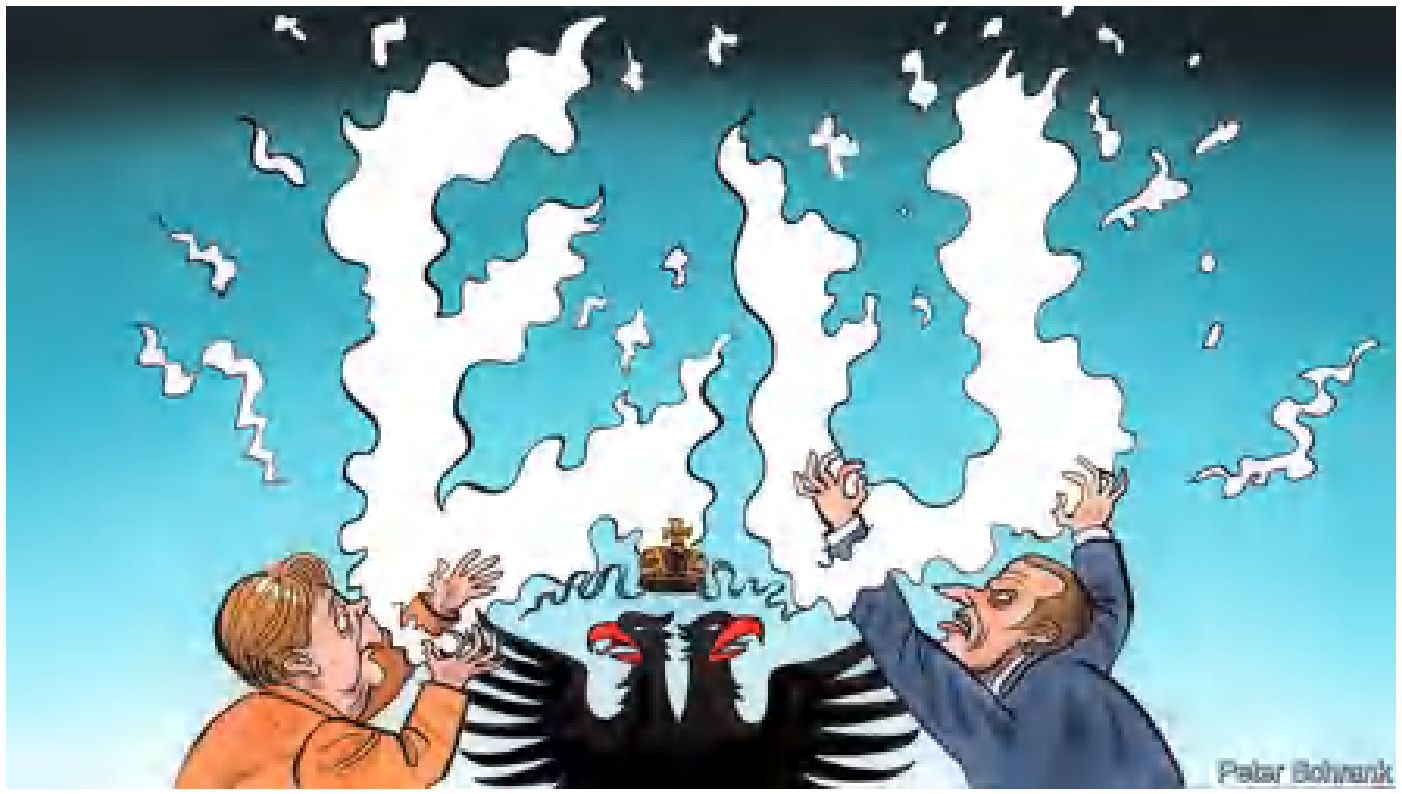

Source: The Economist (2019). 'Europe’s gaseous political alliances. The old Franco-German pact has given way to shifting coalitions", 22 June 2019

It is within this visual context that the Economist concedes that "the more the EU gains members, shrinks in relative global weight and faces ever-tougher circumstances, the more it struggles to present a common front". Furthermore "the geometry of European power", where the old centre-right and centre-left families no longer span Europe, is becoming "messy", while three countries are becoming more influential: Spain, the Netherlands and Austria. The article draws the conclusion that even though these countries are "too disparate to act as a bloc", they may help "the French and the Germans build new coalitions". The final words are a quote from a researcher, according to whom European politics is no longer made of "solid" blocs, which used to be the case. Instead "political coalitions come together for brief periods like clouds of smoke, then are blown apart again", taking the shape of "gaseous constellations" that are likely to define Europe's politics in the coming years.

There are two articles that offer a convincing explanation of why Brexit will have serious implications for the EU's foreign policy. The headline of E4 explicitly states that 
Britain and the EU will remain close even after Brexit, citing the Netherlands yet again as an illustration of the forces driving that cooperation. Written back in 2018, the commentary dwells on the impact that "the dragging on Brexit monster" will have on the bilateral trade between the UK and the Netherlands, "among London's closest EU allies". A common refrain in The Hague and other capitals is that whatever the form of Brexit - soft, hard or no-deal - "it would now be better to have done with it". Calling for speeding up the Brexit talks, the EU is determined not to let Britain leave the club. What raises concerns is "the competitive threat of an offshore Britain that undercuts European regulatory standards", as well as "post-Brexit Britain's geopolitical divergence and the spectre of one of Europe's few serious security powers pivoting towards Donald Trump's America or China". The forces of political, security and economic reality bringing Britain and continental Europe together all make the case for Britain's remaining in the club to pursue its interests.

In the cartoon the two protagonists are clearly designated - the EU and the UK. The $U$ in the EU is drawn in the form of a horseshoe magnet and is painted in the colours of the Dutch national flag, whereas the $\mathrm{E}$ in $\mathrm{EU}$ is golden. The relations between the two sides have been illustrated by the UK's representation as a jug turned upside down. The craftsman working at home tends to keep his gadgets such as screws and washers in a jar. The jar with the Union Jack and the widgets scattered around are a symbol of a situation representing an incident. The EU in the form of a magnet is quite near, which attracts the widgets, parts of which are already glued to it. The major accent in the picture is the diagonal that suggests the natural attraction between the magnet and the small widgets, which in turn are drawn as important linking devices.

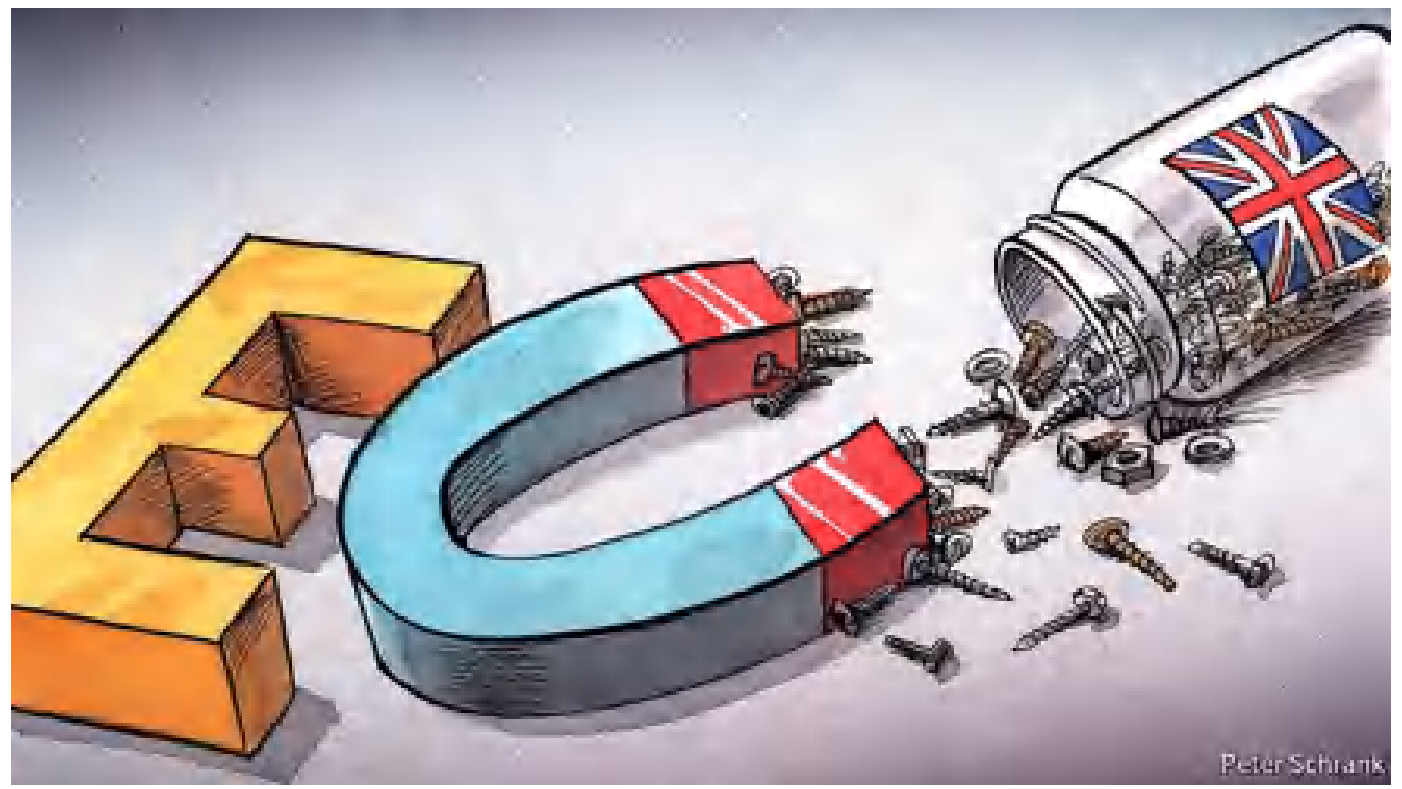

Source: The Economist (2018). "Britain and the EU will remain close even after Brexit, To understand the forces pushing them to co-operate, consider the Netherlands", 2 November 2018 
Written back in March 2019, the E10 commentary highlights the rampant fears that "a divorce could make Britain desperate for trade deals with giant partners like America, China and others" and that "over time those actors could impose conditions that peel Britain away from Europe's foreign policy, leaving it in a position similar to that of Turkey: a semi-European player with unpredictable foreign entanglements". The Americans and then Donald Trump's White House could possibly pressure Britain into withdrawal from the Iran nuclear deal and from "European sanctions and weapons-export policies". As a senior EU diplomat suggests, "the price of a trade deal with China could be British acquiescence to Beijing's ambitions in the South China Sea. According to others, Britain could "sign up to the "belt and road" infrastructure programme or further open its critical infrastructure to Chinese money". The Economist quotes Le Monde's correspondent in London, who imagines Britain becoming "tax haven at Europe's gates" and "China's Trojan horse in Europe". By way of conclusion, the global media sums up the reasons for concerns about Britain among the continentals. Not only should Brexit negotiations be speeded up but also the EU member states should give up their complacency and take "their own geopolitical situation more seriously". There has been little action about seeking "strategic autonomy" from America, stepping up "efforts to curb Russian-backed political interference" or the introduction of a screening mechanism for Chinese investments.

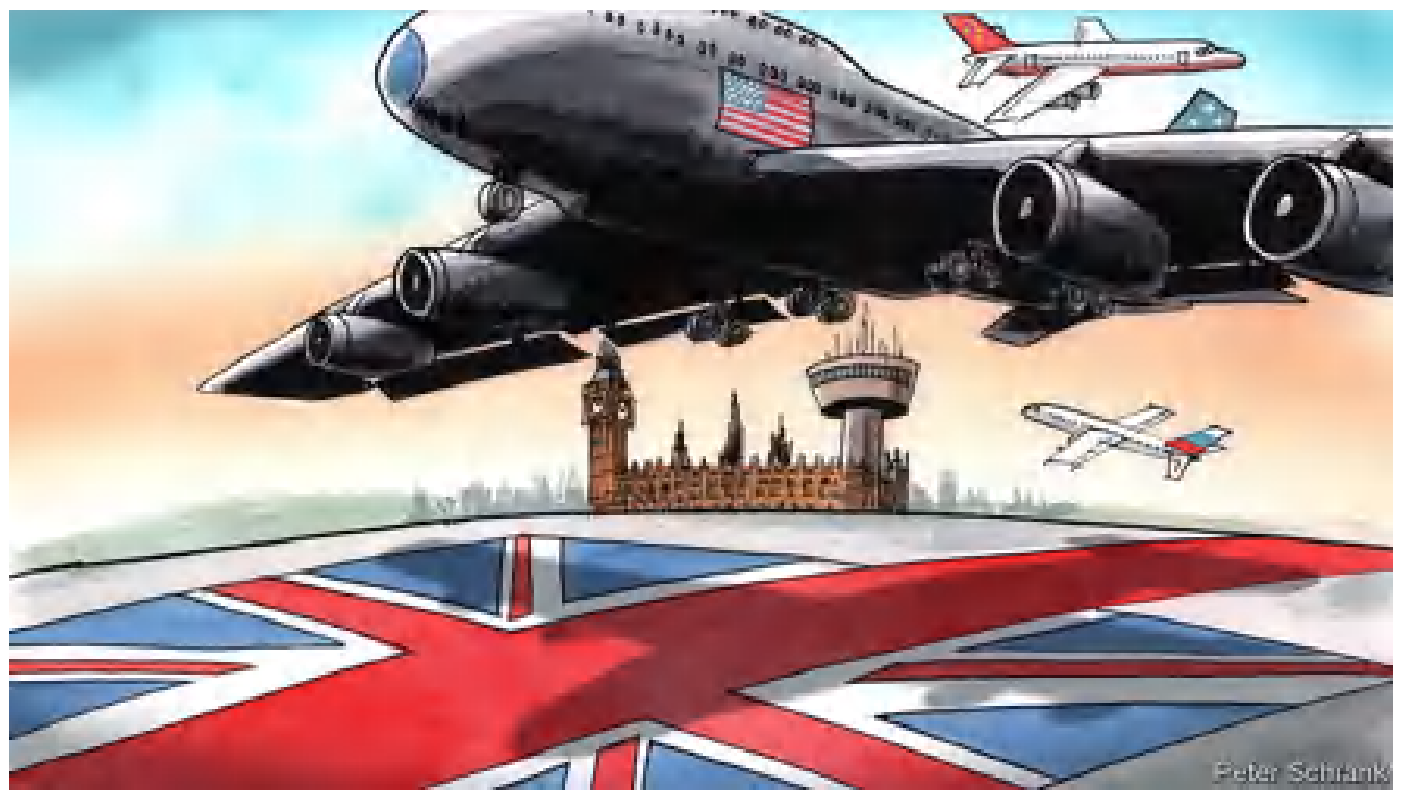

Source: The Economist (2019). "Britain's neighbours fret that it could drift away, And into the arms of non-European powers", 30 March 2019

At the center of the picture is the British Parliament with Big Ben. The impression is created that the picture represents a huge airport, which metaphorically stands for Britain's ties and connections with the world. This suggestion is further enhanced by the 
absurd flight control tower at one side of parliament. The three major superpowers are metaphorically represented by three airplanes.

What is foregrounded is the readily recognizable commercial and passenger airplane the American Boeing 747 (jumbo jet), which is apparently preparing to land on the vast British territory, suggested by its landing gear and fully deployed flaps. This gigantic aircraft has cast an enormous shadow and has taken the contours of more than half of the Union Jack. The picture bears a strong resemblance to the sky above Heathrow Airport, where several airplanes could easily be spotted. There is one Chinese and one Russian plane, judging by the national flags drawn on their tails. It is hard to establish the silhouette of the Russian aircraft, yet the airliner is apparently taking off. The Chinese airplane of an unknown brand is obviously powerful, given that it has four engines. However, it cannot land and is circling above. In conclusion, this is how they are depicted. From Big Ben's perspective, Russia's aircraft is departing, the Chinese one is circling around waiting for permission to land issued by the flight control tower. The US liner is approaching the British runway (you can almost hear the engine roaring).

E17 sets out to outline the two possible paths for Europe. The EU is described as a "sprawling, labyrinthine, many-centred thing" that "tends to move either very slowly or very fast, with shifts creeping forwards over years or suddenly flashing past in hours at late-night summits" in which national capitals "can feel like different universes, with their own electoral and economic cycles, personalities, in-jokes, taboos, histories, myths and ideological constellations". Its history shows that sunnier prospects due to "eastward expansion, transatlantic rifts and a mild economic climate" in the early 2000 were later on replaced by gloomier ones as a result of the Eurozone and migration crises, terror attacks and Britain's vote to leave, when the EU was admittedly "paralysed by its divisions and doomed to extremism, destitution and collapse". Now "the picture is cheerier" - economic recovery has been accompanied by the EU's world leadership in trade liberalisation and technology regulation. This rosy view is fully expressed by French President Macron.

The picture, featuring Charlemagne (also known as Karl and Charles the Great), holding two Tarod cards, symbolizes the two distinct paths of development the EU is faced with. According to the first "mildly positive" path, the EU "muddles its way towards a multi-tier structure in which overlapping and concentric circles of states can better co-operate" and where:

"A group centred on France and Germany creates a common asylum system, the Nordics and the Baltics build a deep digital-services union, and militarily adventurous states like France and Italy complement NATO with midsized interventions close to Europe. A possible reduction and pooling of risk in the euro zone paves the way for modest progress on banking union and closer fiscal co-ordination. Europe enters the 2030s as a more hard-nosed figure, with a patchwork of shared interests. Though not comparable in military or technological power to America or China, it is a relevant broker between them".

Both Tarod cards expose the EU's vulnerability. The one on the right shows the Star card in which a naked woman is kneeling at the edge of a small pool, holding two containers 
of water: one in her left hand (the subconscious) and one in her right (the conscious). She pours the water out to nourish the earth and to continue the cycle of fertility, represented by the lush greenery around her. The woman has one foot on the ground, representing her practical abilities and good common sense, and the other foot in the water, representing her intuition and inner resources and listening to her inner voice. She is naked, which comes to represent her vulnerability and purity under the vastness of the starry night sky.

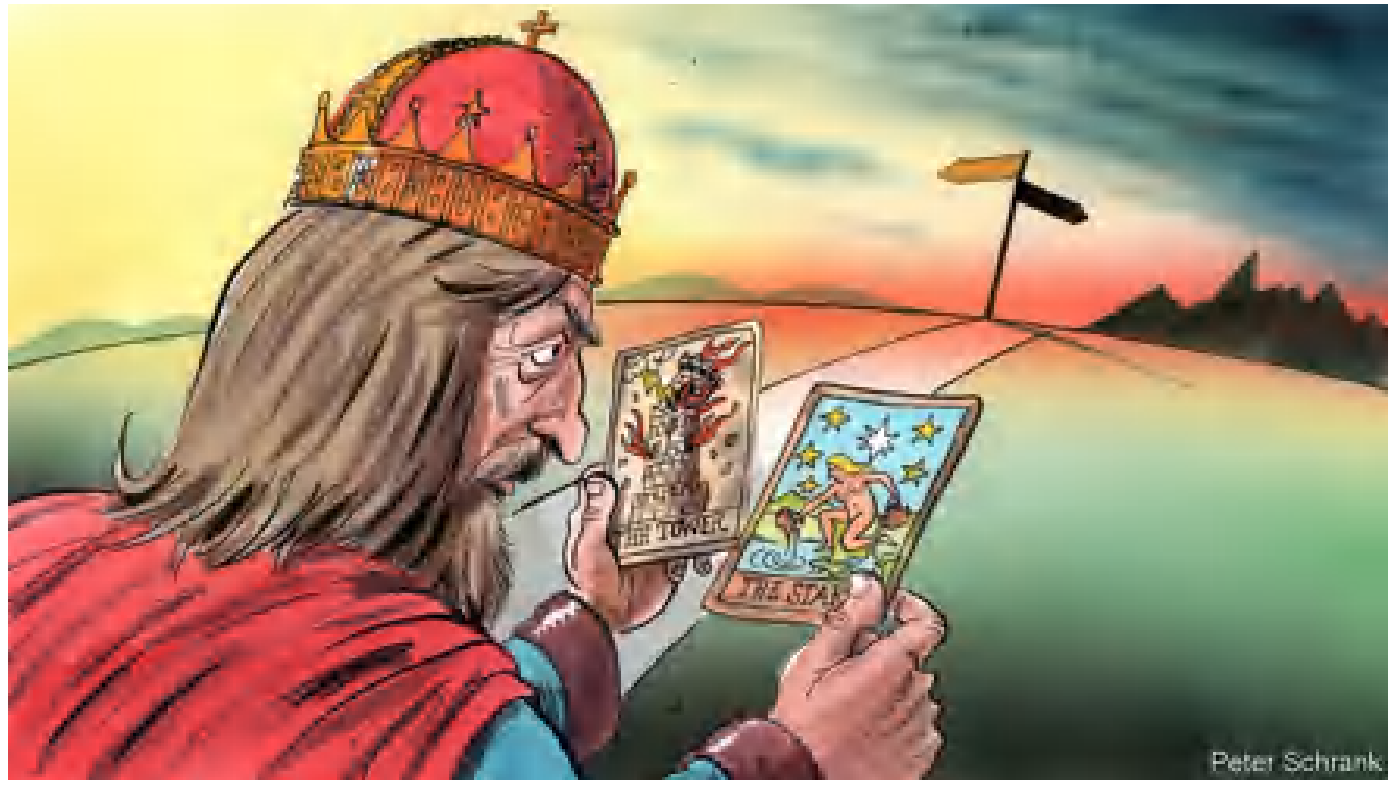

Source: The Economist (2019). "Reading the cards, Our outgoing columnist spies two possible future paths for Europe", 14 November 2019

In the second more negative scenario, the EU's decline is steeper, as the union is faced with an economic slowdown, a split between a "northern and a southern euro, a grind of outside challenges, from technological disruption and migration to terrorism and meddling foreign powers". Amid anti-integration mood and plummeting public support, populists "paralyse fragmented legislatures and shape a more nationalist, less co-operative agenda". As a result the EU enters the 2030s "in one piece, but divided and less relevant, its high relative living standards fraying as Europe falls behind economic rivals and its population ages and shrinks". This scenario is suggested by the right Tarod card in which a tall tower perched on the top of a rocky mountain, where lightning has set the building alight representing a scene of chaos and destruction.

\section{Conclusions}

The Economist resorts to its discursive strategy of the interplay between headline, subheading and cartoon to make an implicit evaluation about post-Brexit EU. By placing 
a political cartoon in the prominent position immediately after the headline and the subheading, the Economic sets a frame within which the meaning of the entire textual body is to be interpreted and the image functions as a visual representation of speech. Those static images convey narratives, intextually based on mundane situations and everyday objects (that most newspaper readers have experienced) or historical events and personages.

As was mentioned at the beginning of this paper, the Economist focuses its analysis on Brexit as a process and output, and its far-reaching implications for the EU's future. It is important to bear in mind that the debate over Europe's future has been exacerbated by populist trends, and the growing discontent with globalization and universalist values. Hence the Brexit vote may be regarded a byproduct of this new world order. All actors and stakeholders involved in Brexit are presumably aware of the broader picture - that the future of Europe is linked to the outcome and the success of Brexit. By shattering many of the long held and essential assumptions of European integration, Brexit threatens the cohesion of the EU and prompts the drawing of a new balance of interests. Furthermore, by triggering Article 50 of the Treaty on the European Union (TEU) for the first time, Brexit largely determines the political, legal and judicial roadmap, and the transaction costs for future exits. In other words the implications of Brexit go beyond the question of the UK's withdrawal from the EU and accommodate the additional transactional and political costs involved.

\section{References}

Ishpekova-Bratanova, K.F. (2020). Identichnost, obraz, natsionalen brand: Balgaria $v$ britanskiya politicheski debat. Sofia: Unison Art [Identity, Image, National Brand: Bulgaria in the British Political Debate].

Ishpekova-Bratanova, K.F. (2021). The Multimodal Construction of Euroscepticism in The Economist, Sofia: Publishing complex - UNWE.

El Rafaie, E. (2003). "Understanding visual metaphor: the example of newspaper cartoons". In: Visual communication, 2, pp. 75-95.

El Refaie, E. (2009). "Metaphor in political cartoons: Exploring audience responses". In: Multimodal Metaphor. Forceville, C. J. and Urios-Aparisi, E., (eds.). Berlin/New York: Mouton de Gruyter, pp. 173-196.

Gibbins, J., (2014). Britain, Europe and National Identity: Self and Other in International Relations, New York: Palgrave Macmillan.

Kress, G. (2000). "Text as the punctuation of semiosis: Pulling at some of the threads". In: Intertextuality and the Media: From Genre to Everyday Life. Ulrike Meinhof and Jonathan Smith (eds.) Manchester: Manchester University Press, pp. 132-154.

Kress, G. and van Leeuwen, T. (1996). Reading Images. London: Routledge.

Kress, G. and van Leeuwen, T. (2001). Multimodal Discourse: The Modes and Media of Contemporary Communication. London: Arnold. 
The Economist (2015). "The open sea. Why British opposition to the EU goes deep", 170ctober 2015; Available at https://www.economist.com/special-report/2015/10/15/theopen-sea (last visited June 17, 2021).

The Economist (2015). "The reluctant European. Though Britain has always been rather half-hearted about the European Union, its membership has been beneficial for all concerned, argues John Peet. It should stay in the club", 17 October 2015; Available at https://www.economist.com/special-report/2015-10-17 (last visited June 17, 2021).

The Economist (2017). "Brexit explodes the ambiguity that underpins Northern Ireland, British voters forgot that the peace deal depended on both sides being part of the European Union", 24 November 2017; Available at https://www.economist.com/ europe/2017/11/25/brexit-explodes-the-ambiguity-that-underpins-northernireland (last visited June 17, 2021).

The Economist (2018). “How the Dutch will take Britain's place in Europe, For the Netherlands Brexit is a threat - and an opportunity", 31 March 2018; Available at https://www.economist.com/europe/2018/03/31/how-the-dutch-will-takebritains-place-in-europe (last visited June 17, 2021).

The Economist (2018). "Britain and the EU will remain close even after Brexit, To understand the forces pushing them to co-operate, consider the Netherlands", 2 November 2018; Available at https://www.economist.com/europe/2019/10/31/ britain-and-the-eu-will-remain-close-even-after-brexit (last visited June 17, 2021).

The Economist (2018). "The power of fish, What the poisonous politics of les poissons means for Brexit", 24 November 2018; Available at https://www.economist.com/ europe/2018/11/24/the-power-of-fish (last visited June 17, 2021).

The Economist (2019). "How Britain and its neighbours misunderstand each other, Both need to learn fast", 26 January 2019; Available at https://www.economist.com/ europe/2019/01/26/how-britain-and-its-neighbours-misunderstand-eachother (last visited June 17, 2021).

The Economist (2019). "Britain's neighbours fret that it could drift away, And into the arms of non-European powers", 30 March 2018; Available at https://www.economist. com/europe/2019/03/28/britains-neighbours-fret-that-it-could-drift-away (last visited June 17, 2021).

The Economist (2019). Europe's gaseous political alliances, The old Franco-German pact has given way to shifting coalitions", The old Franco-German pact has given way to shifting coalitions", 22 June 2019; Available at https://www.economist.com/ europe/2019/06/22/europes-gaseous-political-alliances (last visited June 17, 2021).

The Economist (2019). "Reading the cards, Our outgoing columnist spies two possible future paths for Europe", 14 November 2019; Available at https://www.economist. com/europe/2019/11/14/reading-the-cards (last visited June 17, 2021). 
The Economist (2020). "Huntington's disease and the clash of civilisation-states, Our new Charlemagne columnist ponders Europe's future", 4 January 2020; Available at https://www.economist.com/europe/2020/01/02/huntingtons-disease-andthe-clash-of-civilisation-states (last visited June 18, 2021).

The Economist (2020). "Why stereotypes rule in Brussels, The EU's de facto capital has a dirty secret", 11 January 2020; Available at https://www.economist.com/ europe/2020/01/11/why-stereotypes-rule-in-brussels (last visited June 19, 2021).

The Economist (2020). "After Brexit, who will be the British of the EU? There are lots of contenders for the New Brit awards, 1 February 2020; Available at https://www. economist.com/europe/2020/01/30/after-brexit-who-will-be-the-british-ofthe-eu (last visited June 17, 2021).

The Economist (2020). "The parable of the plug, How plugs explain the potential and limits of the EU's strange superpower", 8 February 2020; Available at https://www. economist.com/europe/2020/02/06/the-parable-of-the-plug (last visited June $18,2021)$.

The Economist (2020). "The EU's recovery fund is a benefit of Brexit, The bloc takes steps that would have been impossible with Britain as a member", 30 May 2020; Available at https://www.economist.com/europe/2020/05/30/the-eus-recovery-fund-isa-benefit-of-brexit (last visited June 20, 2021).

The Economist (2020). "The revenge of strategic yogurt, How the EU started speaking French when it comes to the economy", 3 October 2020; Available at https://www. economist.com/europe/2020/10/03/the-revenge-of-strategic-yogurt (last visited June 19, 2021).

The Economist (2020). "A Biden presidency would offer Emmanuel Macron a tempting opportunity, His Trump-whispering did not work. Can France's president master Biden-blarneying?", 29 October 2020; Available at https://www.economist.com/ europe/2020/10/31/a-biden-presidency-would-offer-emmanuel-macron-atempting-opportunity (last visited June 15, 2021).

The Economist (2020). "Life beyond Europe's rainbow curtain, For gay people, the continent is still divided", 21 November 2020; Available at https://www.economist. com/europe/2020/11/21/life-beyond-europes-rainbow-curtain (last visited June 27, 2021).

The Economist (2021). "The botched launch of "Cyberpunk 2077", Europe's video-game sector is a mixture of triumph and failure", 16 January 2021; Available at https://www. economist.com/europe/2021/01/16/the-botched-launch-of-cyberpunk-2077 (last visited June 10, 2021).

Scheufele, D. (1999). "Framing as a Theory of Media effect". In: Journal of Communication. 49 (1), pp. 103-122. 
Scheufele, D. A. and Tewksbury, D. (2007). "Framing, Agenda Setting, and Priming: The Evolution of Three Media Effects Models". In: Journal of Communication, 57, pp. 9-20.

Schimmelfennig, F. (2018). "Brexit: Differentiated Disintegration in the European Union". In: Journal of European Public Policy, vol. 25, issue 8, April 2018; Available at https://www.researchgate.net/publication/324762365_Brexit_differentiated_ disintegration_in_the_European_Union (last visited June 22, 2021).

Tombs, R. (2015). The English and their History. London: Penguin Random House.

Waite, A. E., 1857-1942. (2005). The Pictorial Key to the Tarot. Mineola, NY: Dover Publications.

\section{Notes}

Table 1: Articles published in the Economist 2017-2021

\begin{tabular}{|c|c|c|c|}
\hline No & date & headline & subheading \\
\hline E1 & 1 Feb 2020 & $\begin{array}{l}\text { After Brexit, who will be the British of the } \\
\text { EU? }\end{array}$ & $\begin{array}{l}\text { There are lots of contenders for the New } \\
\text { Brit awards }\end{array}$ \\
\hline E2 & $\begin{array}{l}30 \text { May } \\
2020\end{array}$ & $\begin{array}{l}\text { The EU's recovery fund is a benefit of } \\
\text { Brexit }\end{array}$ & $\begin{array}{l}\text { The bloc takes steps that would have } \\
\text { been impossible with Britain as a member }\end{array}$ \\
\hline E3 & 24 Nov 2017 & $\begin{array}{l}\text { Brexit explodes the ambiguity that } \\
\text { underpins Northern Ireland }\end{array}$ & $\begin{array}{l}\text { British voters forgot that the peace deal } \\
\text { depended on both sides being part of the } \\
\text { European Union }\end{array}$ \\
\hline E4 & 2 Nov 2018 & $\begin{array}{l}\text { Britain and the EU will remain close } \\
\text { even after Brexit }\end{array}$ & $\begin{array}{l}\text { To understand the forces pushing them to } \\
\text { co-operate, consider the Netherlands }\end{array}$ \\
\hline E5 & 29 Oct 2020 & $\begin{array}{l}\text { A Biden presidency would offer Em- } \\
\text { manuel Macron a tempting opportu- } \\
\text { nity }\end{array}$ & $\begin{array}{l}\text { His Trump-whispering did not work. Can } \\
\text { France's president master Biden-blarney- } \\
\text { ing? }\end{array}$ \\
\hline E6 & 24 Nov 2018 & The power of fish & $\begin{array}{l}\text { What the poisonous politics of les pois- } \\
\text { sons means for Brexit }\end{array}$ \\
\hline E7 & 31 Mar 2018 & $\begin{array}{l}\text { How the Dutch will take Britain's } \\
\text { place in Europe }\end{array}$ & $\begin{array}{l}\text { For the Netherlands Brexit is a threat - } \\
\text { and an opportunity }\end{array}$ \\
\hline E8 & 22 Jun 2019 & Europe's gaseous political alliances & $\begin{array}{l}\text { The old Franco-German pact has given } \\
\text { way to shifting coalitions }\end{array}$ \\
\hline E9 & 11 Jan 2020 & Why stereotypes rule in Brussels & The EU's de facto capital has a dirty secret \\
\hline E10 & 30 Mar 2019 & $\begin{array}{l}\text { Britain's neighbours fret that it could drift } \\
\text { away }\end{array}$ & $\begin{array}{l}\text { And into the arms of non-European } \\
\text { powers }\end{array}$ \\
\hline E11 & 8 Feb 2020 & The parable of the plug & $\begin{array}{l}\text { How plugs explain the potential and limits } \\
\text { of the EU's strange superpower }\end{array}$ \\
\hline
\end{tabular}




\begin{tabular}{|c|l|l|l|}
\hline No & \multicolumn{1}{|c|}{ date } & \multicolumn{1}{|c|}{ headline } & \multicolumn{1}{c|}{ subheading } \\
\hline E12 & 26 Jan 2019 & $\begin{array}{l}\text { How Britain and its neighbours mis- } \\
\text { understand each other }\end{array}$ & Both need to learn fast \\
\hline E13 & 3 Oct 2020 & The revenge of strategic yogurt & $\begin{array}{l}\text { How the EU started speaking French } \\
\text { when it comes to the economy }\end{array}$ \\
\hline E14 & 4 Jan 2020 & $\begin{array}{l}\text { Huntington's disease and the clash of } \\
\text { civilisation-states }\end{array}$ & $\begin{array}{l}\text { Our new Charlemagne columnist ponders } \\
\text { Europe's future, }\end{array}$ \\
\hline E15 & 21 Nov 2020 & $\begin{array}{l}\text { Life beyond Europe's rainbow curtain } \\
\text { E16 }\end{array}$ & $\begin{array}{l}\text { For gay people, the continent is still } \\
\text { divided }\end{array}$ \\
\hline E17 & 14 Nov 2019 & $\begin{array}{l}\text { The botched launch of “Cyberpunk } \\
2077 \text { " }\end{array}$ & $\begin{array}{l}\text { Europe's video-game sector is a mixture } \\
\text { of triumph and failure }\end{array}$ \\
\hline
\end{tabular}

